Check for updates

Cite this: RSC Adv., 2017, 7, 44619

Received 7th August 2017

Accepted 1st September 2017

DOI: $10.1039 / \mathrm{c} 7 \mathrm{ra0} 8704 \mathrm{~g}$

rsc.li/rsc-advances

\section{Nanocasting synthesis of an iron nitride-ordered mesopore carbon composite as a novel electrode material for supercapacitors $\dagger$}

\author{
Liyang Xu, (D) Li Sun, ${ }^{*}$ Jian Feng, Linlin Qi, Ishaq Muhammad, Jabeen Maher, \\ Xiaoyu Cheng and Weiming Song*
}

\begin{abstract}
Herein, a series of novel iron nitride $\left(\mathrm{Fe}_{2} \mathrm{~N}\right)$ /cubic-ordered mesoporous carbon (OMC) composites $\left(\mathrm{Fe}_{2} \mathrm{~N}(\mathrm{OMMC})\right.$ were synthesized via a facile nanocasting route and ammonia calcination. Physical characterization results indicate that small non-aggregated $\mathrm{Fe}_{2} \mathrm{~N}$ nanoparticles were evenly distributed on the external surface and in the pores of the carbon material with a linear array of mesopores in a regular interval arrangement. An electrochemical test was carried out using $\mathrm{Fe}_{2} \mathrm{NaOMC}$ as a negative electrode of a supercapacitor in $6 \mathrm{~mol} \mathrm{~L}^{-1} \mathrm{KOH}$ aqueous electrolytes. The results indicated that the obtained $\mathrm{Fe}_{2} \mathrm{NaOMC}-2$ exhibited a superior specific capacitance of $547 \mathrm{~F} \mathrm{~g}^{-1}$ at $1 \mathrm{mV} \mathrm{s}^{-1}$ and $520 \mathrm{~F} \mathrm{~g}^{-1}$ at $0.5 \mathrm{~A} \mathrm{~g}^{-1}$, an excellent rate capability (398 $\mathrm{F} \mathrm{g}^{-1}$ at $20 \mathrm{~A} \mathrm{~g}^{-1}$ with capacitance retention of $76 \%$ ), and an outstanding cycling stability. After 1000 cycles, the specific capacitance retention of $\mathrm{Fe}_{2} \mathrm{NaOMC}-2$ remained $85 \%$, which was much higher than $28 \%$ of the bare $\mathrm{Fe}_{2} \mathrm{~N}$.
\end{abstract}

\section{Introduction}

In recent years, as there is an increasing requirement for the storage and utilization of a mass of energy, electrochemical devices have been developing rapidly. Among them, supercapacitors have attracted significant attention due to their high energy density, great rate capacity, and cycling stability. ${ }^{1-3}$ Thus, many researchers are engaged in the investigation and research of electrode materials for supercapacitors. Transition metal oxides $\left(\mathrm{Fe}_{2} \mathrm{O}_{3}, \mathrm{Co}_{3} \mathrm{O}_{4}\right.$, and $\left.\mathrm{MnO}_{2}\right)$, bimetallic oxides, and hydroxides are always used as electrode materials because of high capacitance of transition metal compounds.4-8 For instance, Yu et al. presented the design and development of novel Ag/PEDOT:PSS-nanopillar/ $\mathrm{MnO}_{2}$ layers by a layer structure for high-performance flexible supercapacitors. This electrode provided excellent specific capacitances of $862 \mathrm{~F} \mathrm{~g}^{-1}$ (based on $\mathrm{MnO}_{2}$ ) at a current density of $2.5 \mathrm{~A} \mathrm{~g}^{-1}$. ${ }^{9}$ Thomas et al. have reported an all-solid-state, energy harvesting and storing ribbon that integrates a solar cell and a supercapacitor. In this device, $\mathrm{MnO}_{2}$ deposited on $\mathrm{Cu}(\mathrm{OH})_{2}$ nanotube arrays was used as an electrode, and the capacitance of the final electrodes was increased to $145.15 \mathrm{mF} \mathrm{cm}{ }^{-2} .^{10}$ However, the high electrical resistivity of transition metal compounds affects the power density; this results in a significant reduction in capacitance

College of Chemistry and Chemical Engineering, Qiqihar University, Qiqihar, Heilongjiang 161006, P. R. China. E-mail: qdsongweiming@163.com; sunli04070215@163.com

$\dagger$ Electronic supplementary information (ESI) available. See DOI: $10.1039 / \mathrm{c} 7 \mathrm{ra} 08704 \mathrm{~g}$ under operation at high-intensity current, which is not expected for electrode materials used in energy utilization and storage systems. ${ }^{11-14}$ Previous reports have proved that transition metal nitrides, such as chromium nitride, cobalt nitride, vanadium nitride, and iron nitride, used as electrode materials for supercapacitors have more advantages than transition metal oxides due to their superior electrical conductivity (4000$55500 \mathrm{~S} \mathrm{~cm}^{-1}$ ) and outstanding pseudocapacitive behaviour. ${ }^{15-18}$ For example, Lu et al. demonstrated a novel core-shell structure in which TiN nanowires were covered with ultrathin amorphous carbon protective layers. This TiN solid-state supercapacitor demonstrated a remarkable $91.3 \%$ retention in aqueous electrolytes after 15000 cycles without any oxidation. ${ }^{19}$ Yu et al. synthesized tungsten oxynitride (WON) nanowires on carbon cloths, and the WON asymmetric supercapacitor anode showed a high volumetric capacitance of $4.95 \mathrm{~F} \mathrm{~cm}^{-3}$ at $12.5 \mathrm{~mA} \mathrm{~cm}{ }^{-3}{ }^{20}$ Metal nitrides are considered to be the most promising representatives of new generation of electrode materials for electrochemical storage device such as lithium-ion batteries (LIBs), fuel cells, sodium-ion batteries, and supercapacitors. ${ }^{21-24}$ The unique nature of $\mathrm{M}$ (metal)- $\mathrm{N}$ (nitride) bonding can provide simultaneous multiple model contributions from metallic, covalent, and ionic bonding. ${ }^{25}$ Moreover, transition metal nitrides may be able to provide similar properties to the noble metals due to their similar electronic structures. ${ }^{26}$

Among many kinds of metal nitrides, $\mathrm{Fe}_{2} \mathrm{~N}$ is recognized as the best choice as a pseudocapacitive electrode material due to its outstanding electrical conductivity, low cost, low resistance, and environmental friendliness. ${ }^{27,28}$ However, in the synthesis of transition metal nitrides, products always form a large 
number of bulks of transition metal nitrides; this leads to low utilization rate of their high capacitances in a strong current system. To overcome this problem and enhance the electrochemical performance, carbon material and transition metal nitride composites have been synthesized by researchers. The carbon materials such as ordered mesoporous carbons (OMC), activated carbons, carbon nanofibers, and carbon nanotubes ${ }^{29-32}$ with a high specific surface area can increase the electric conductivity of composite materials and provide a carbon skeleton to support the uniform deposition of metal nitride particles, thus increasing the utilization efficiency of transition metal nitrides. ${ }^{33-36}$

There are only a few investigations and research on the use of iron nitride as an electrode material for supercapacitors. Zhu et al. reported that $\mathrm{Fe}_{2} \mathrm{~N} /$ graphene was synthesized via deposition of $\mathrm{ZnO}$ on a graphene nanosheet surface. Then, $\mathrm{ZnO}$ and $\mathrm{Fe}^{3+}$ were subjected to ion-exchange and finally annealed under an atmosphere of ammonia. The synthetic composite tested as an electrode in an electrolyte of $1 \mathrm{M} \mathrm{LiCl}$ showed a specific capacitance of $170 \mathrm{~F} \mathrm{~g}^{-1}$ at a scan rate of $10 \mathrm{mV} \mathrm{s}^{-1}$ and $120 \mathrm{~F} \mathrm{~g}^{-1}$ at $100 \mathrm{mV} \mathrm{s}^{-1}$ in a three-electrode system. ${ }^{37} \mathrm{~A} \mathrm{Fe}_{2} \mathrm{~N} /$ activated carbon composite was fabricated via hydrothermal and ammonia treatments by Agata Śliwaka et al. The specific capacitance of this composite used as an electrode active material for supercapacitors operating in $6 \mathrm{M}$ $\mathrm{KOH}$ is 498 and $371 \mathrm{~F} \mathrm{~g}^{-1}$ at the scan rates of 10 and $100 \mathrm{mV} \mathrm{s}^{-1}$, respectively. ${ }^{38}$ In this study, we first report the synthesis of a series of novel $\mathrm{Fe}_{2} \mathrm{~N} @$ ordered cubic mesoporous carbon composites ( $\left.\mathrm{Fe}_{2} \mathrm{~N} @ \mathrm{OMC}\right)$, and the resultant best composite as an active material of the electrode for supercapacitors operating in $6 \mathrm{M} \mathrm{KOH}$ shows a superior capacitance values of $506 \mathrm{~F} \mathrm{~g}^{-1}$ at the scan rates of $10 \mathrm{mV} \mathrm{s}^{-1}$ and $435 \mathrm{~F} \mathrm{~g}^{-1}$ at the scan rates of $100 \mathrm{mV} \mathrm{s}^{-1}$.

\section{Experimental}

\subsection{Materials}

Triblock copolymer Pluronic P123 $\left(M_{\mathrm{W}}=5800\right.$, PEG-PPG-PEG) was purchased from Macklin Biochemical Co. Ltd (Shanghai, China). Iron(III) chloride hexahydrate $\left(\mathrm{FeCl}_{3} \cdot 6 \mathrm{H}_{2} \mathrm{O}\right), \mathrm{HCl}$ water solution (AR, 36.0-38.0\%), and other chemicals were supplied by Kemiou Chemical Reagent Co. Ltd (Tianjin, China).

\subsection{Synthesis of the KIT- 6 template and OMC}

The cubic three-dimensional (3D) ordered mesoporous silica template KIT- 6 was fabricated using the synthesis procedures reported in the literature, ${ }^{29}$ and the $3 \mathrm{D}$-ordered mesoporous carbon (OMC) materials were prepared using sucrose as a carbon source and KIT-6-ordered mesoporous silica as a hard template. As shown in Fig. 1, $1.00 \mathrm{~g}$ of sucrose precursor and $1.00 \mathrm{~g}$ of KIT- 6 were added to $20 \mathrm{~mL}$ DI water and stirred to obtain a homogeneous mixture. The sucrose precursor was made to continuously flow into a mesoporous silica template by vacuum impregnation at room temperature. The obtained mixture was dried at $80^{\circ} \mathrm{C}$, and then, the dried solid was ground to form a fine powder. This powder was then calcined at $800{ }^{\circ} \mathrm{C}$

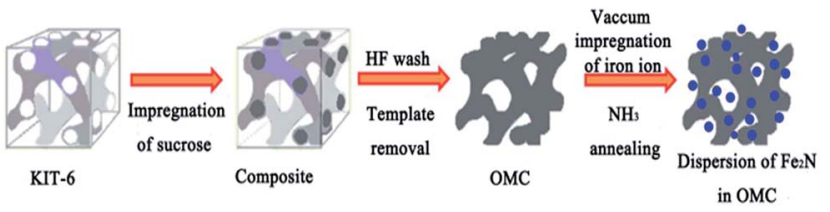

Fig. 1 Schematic for the nanocasting synthesis of $\mathrm{OMC}$ and $\mathrm{Fe}_{2}-$ NaOMC composites.

under an inert atmosphere at a temperature ramp rate of $2{ }^{\circ} \mathrm{C} \min ^{-1}$ and kept for $3 \mathrm{~h}$. The calcined product was then removed out of the silica template using $10 \mathrm{wt} \% \mathrm{HF}$ solution, and pure OMC was obtained.

\subsection{Synthesis of $\mathrm{Fe}_{2} \mathrm{~N}, \mathrm{Fe}_{2} \mathrm{~N} @ \mathrm{OMC}-1, \mathrm{Fe}_{2} \mathrm{~N} @ \mathrm{OMC}-2$, and $\mathrm{Fe}_{2} \mathrm{~N} @ O M C-3$}

$\mathrm{Fe}_{2} \mathrm{~N}$ was prepared by a straightforward route. First, $1.00 \mathrm{~g}$ $\mathrm{FeCl}_{3} \cdot 6 \mathrm{H}_{2} \mathrm{O}$ was dried at $80{ }^{\circ} \mathrm{C}$ in a vacuum oven, and then anhydrous $\mathrm{FeCl}_{3}$ was ground to form a fine powder. Subsequently, the powder sample was tiled into a thin layer at the bottom of a quartz boat and calcined at $800^{\circ} \mathrm{C}$ for $2 \mathrm{~h}$ at a heating rate of $5^{\circ} \mathrm{C} \mathrm{min}^{-1}$ under the flow of ammonia at a rate of $100 \mathrm{~mL} \min ^{-1}$. The calcined product was $\mathrm{Fe}_{2} \mathrm{~N}$. $\mathrm{Fe}_{2} \mathrm{~N} @ \mathrm{OMC}-1$, $\mathrm{Fe}_{2} \mathrm{~N} @ O M C-2$, and $\mathrm{Fe}_{2} \mathrm{~N} @ O M C-3$ were prepared using a vacuum nanocasting method, as shown in Fig. 1. OMC weighing $0.10 \mathrm{~g}$ was first dispersed in $20 \mathrm{~mL}$ of DI water under sonication for $2 \mathrm{~h}$, and different amounts $(0.25 \mathrm{~g}, 0.50 \mathrm{~g}$, and $1.00 \mathrm{~g}$ ) of $\mathrm{FeCl}_{3} \cdot 6 \mathrm{H}_{2} \mathrm{O}$ were added to $20 \mathrm{~mL}$ DI water under stirring for $8 \mathrm{~h}$ to obtain a homogeneous mixture. The subsequent steps (drying, grinding, and calcination) are the same as those in the procedure for preparing $\mathrm{Fe}_{2} \mathrm{~N}$. The obtained products were $\mathrm{Fe}_{2} \mathrm{~N} @ \mathrm{OMC}-1, \mathrm{Fe}_{2} \mathrm{~N} @ \mathrm{OMC}-2$, and $\mathrm{Fe}_{2} \mathrm{~N} @ \mathrm{OMC}-3$.

\subsection{Material characterization}

The sample materials were characterized by X-ray diffraction (XRD, D8 FOCUS, Bruker, Germany) with Cu K $\alpha 1.5406$ A radiation. The microstructure of the sample materials was observed using a transmission electron microscope (TEM, H-7650, Hitachi, Japan) at a voltage of $100 \mathrm{kV}$, a high-resolution transmission electron microscope (HRTEM, Tecnai G2 F20, FEI, USA) at a voltage of $200 \mathrm{kV}$, and a scanning electron microscope (SEM, S-3400, Hitachi, Japan). Thermogravimetric analysis (TGA) was performed using a Pyris1TGA (PerkinElmer Instruments) under an air atmosphere at a heating rate of $5{ }^{\circ} \mathrm{C} \mathrm{min}^{-1}$. Nitrogen sorption analysis was conducted at $77 \mathrm{~K}$ using a physical adsorption instrument (AUTOSORB-1, Quantachrome, USA). The specific surface area was determined by the Brunauer-Emmett-Teller (BET) method, and the pore size distribution calculation was derived from the adsorption branches of the isotherms by the Barrett-Joyner-Halenda (BJH) theory. X-ray photoelectron spectroscopy (XPS) was performed using a spectrometer (ESCALAB 250Xi, Thermo Fisher, USA) with $\mathrm{Al} \mathrm{K} \alpha$ radiation (1486.6 eV). The shifts in energy (charging) of the XPS spectra were calibrated using the $C$ 1s peak at $284.6 \mathrm{eV}$ as a reference peak. 


\subsection{Electrochemical characterization}

The electrochemical measurements were carried out using a standard three-electrode cell, where $\mathrm{Pt}$ foil and $\mathrm{Hg} / \mathrm{HgO}$ electrode were used as the counter and reference electrodes, respectively, in a $6 \mathrm{M} \mathrm{KOH}$ aqueous solution. The working electrodes were prepared as follows:

The clean nickel foams $\left(1 \times 10 \mathrm{~cm}^{2}\right)$ were prepared in advance. Then, $1 \times 1 \mathrm{~cm}^{2}$ nickel foams were coated by mixing 80 wt $\%$ active material (OMC, $\mathrm{Fe}_{2} \mathrm{~N}, \mathrm{Fe}_{2} \mathrm{~N} @ \mathrm{OMC}-1, \mathrm{Fe}_{2}$ $\mathrm{N} @ \mathrm{OMC}-2$, or $\left.\mathrm{Fe}_{2} \mathrm{~N} @ O M C-3\right)$ with $10 \mathrm{wt} \%$ polytetrafluoroethylene (PTFE) as a binding agent and $10 \mathrm{wt} \%$ acetylene black conductor. The mass of the active materials on each electrode was approximately $4.00 \mathrm{mg}$. Cyclic voltammetry (CV) and galvanostatic charge/discharge measurements were carried out by an electrochemical work station (CHI660E). The electrochemical impedance spectroscopy (EIS) measurement was performed using an electrochemical work station (PAR VersaSTAT 4) at an open circuit potential from $100 \mathrm{kHz}$ to $0.01 \mathrm{~Hz}$ with an alternating current amplitude of $5 \mathrm{mV}$. The specific capacitance $\left(C, \mathrm{~F} \mathrm{~g}^{-1}\right)$ of the electrode materials can be calculated from the galvanostatic discharged curves and the cyclic voltammograms according to the following equations:

$$
\begin{gathered}
C=\frac{I \Delta t}{U m} \\
C=\frac{\int I \mathrm{~d} t}{\nu m}
\end{gathered}
$$

where $I$ is the current (A), $U$ is the operating cell voltage (V), $t$ is the time (s), $\nu$ is the scan rate $\left(\mathrm{V} \mathrm{s}^{-1}\right)$, and $m$ is the mass of the active material in the electrode $(\mathrm{g})$.

\section{Results and discussion}

X-ray diffraction (XRD) analysis confirmed the presence of $\mathrm{Fe}_{2} \mathrm{~N}$ in all the samples except OMC, as shown in Fig. 2. The peaks at $2 \theta=37.4$ (021), 40.9 (200), 43.0 (121), 56.9 (221), 68.0 (023), and $76.0^{\circ}(321)$ are consistent with the orthorhombic $\mathrm{Fe}_{2} \mathrm{~N}$ phase (JC-PDS \#50-0958). No iron oxide phase was observed. These

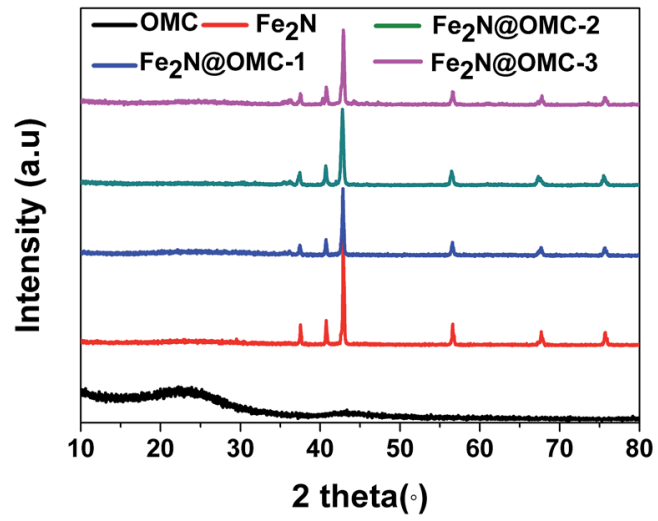

Fig. 2 The XRD patterns of OMC, $\mathrm{Fe}_{2} \mathrm{~N}, \mathrm{Fe}_{2} \mathrm{NaOMC}-1, \mathrm{Fe}_{2} \mathrm{NaOMC}-2$, and $\mathrm{Fe}_{2} \mathrm{NaOMC}-3$. results support the complete conversion of $\mathrm{FeCl}_{3}$ into $\mathrm{Fe}_{2} \mathrm{~N}$ by $\mathrm{NH}_{3}$ annealing, as shown in eqn (3). The two broad peaks at approximately 23.8 and $43.6^{\circ}$ in the XRD pattern of OMC arise from the (002) and (100) planes of graphite-type carbon, respectively.

$$
\mathrm{FeCl}_{3}+\mathrm{NH}_{3} \stackrel{\text { heat }}{\longrightarrow} \mathrm{Fe}_{2} \mathrm{~N}+\mathrm{HCl}
$$

Transmission electron microscopy (TEM) was performed to further observe the microstructure and the distribution of $\mathrm{Fe}_{2} \mathrm{~N}$ particles for the synthesized products. The TEM image of OMC shows a highly ordered mesoporous structure with a linear array of mesopores in a regular interval arrangement (Fig. 3a). ${ }^{39}$ The TEM image of $\mathrm{Fe}_{2} \mathrm{~N} @-\mathrm{OMC}-2$ indicates a homogeneous distribution of small and non-agglomerative $\mathrm{Fe}_{2} \mathrm{~N}$ nanoparticles (with a diameter of 10-30 nm) on the surface of OMC, as shown in Fig. 3c. By contrast, the TEM image of $\mathrm{Fe}_{2} \mathrm{~N} @ O M C-1$ shows that the well-ordered structure is still retained and the presence of $\mathrm{Fe}_{2} \mathrm{~N}$ particles almost cannot be observed in Fig. $3 \mathrm{~b}$. On the other hand, the image of $\mathrm{Fe}_{2} \mathrm{~N} @ O M C-3$ revealed an uneven distribution of big $\mathrm{Fe}_{2} \mathrm{~N}$ particles on the surface of OMC, and the ordered structure was severely damaged, as shown in Fig. 3d. The high-resolution TEM (HRTEM) image (Fig. 3e) exhibits well-resolved lattice fringes, again confirming the highcrystalline nature of the $\mathrm{Fe}_{2} \mathrm{~N}$ nanoparticles for $\mathrm{Fe}_{2} \mathrm{~N} @ \mathrm{OMC}-2$. The lattice fringe spacings are measured to be 0.21 and
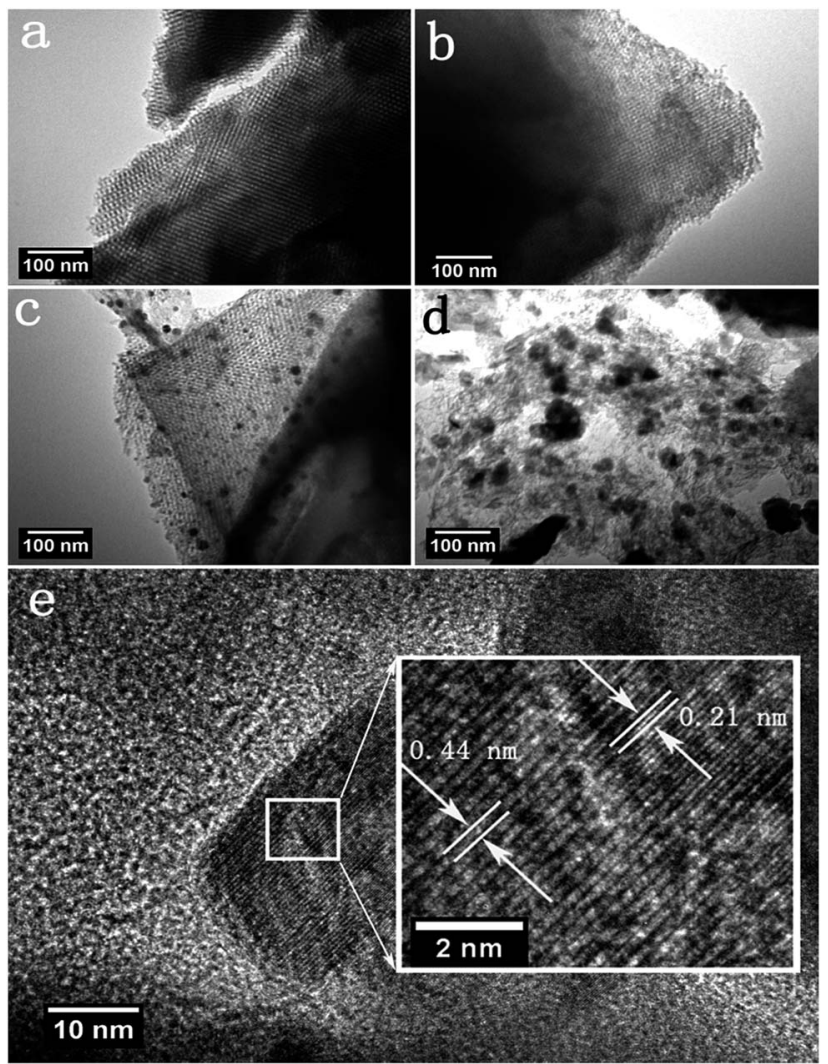

Fig. 3 TEM images of OMC (a), $\mathrm{Fe}_{2} \mathrm{NaOMC}-1$ (b), $\mathrm{Fe}_{2} \mathrm{NaOMC}-2$ (c), and $\mathrm{Fe}_{2} \mathrm{NaOMC}-3$ (d). HRTEM image of $\mathrm{Fe}_{2} \mathrm{NaOMC}-2$ (e). 
$0.44 \mathrm{~nm}$, which are assigned to the $d$-spacing of (102) and (200) planes of the orthorhombic $\mathrm{Fe}_{2} \mathrm{~N}$ phase (JC-PDS \#50-0958), respectively, and the result is consistent with that of the analysis of XRD. ${ }^{40}$ X-ray energy-dispersive spectrometer (EDS) elemental mapping was performed to further confirm the element distribution. The SEM image (Fig. S1a ESI $\dagger$ ) of $\mathrm{Fe}_{2} \mathrm{~N} @ O M C-2$ and its EDS elemental mapping data (Fig. S1c and d ESI $\dagger$ ) show that the particles are mainly $\mathrm{C}$ (red), Fe (purple), and $\mathrm{N}$ (green), which are uniformly distributed in $\mathrm{Fe}_{2} \mathrm{~N} @ \mathrm{OMC}-2$.

The content of $\mathrm{Fe}_{2} \mathrm{~N}$ calculated from thermogravimetric analysis (Fig. S2 and Table S1, ESI $\dagger$ ) was 28.1, 40.3, and 57.1 wt\% in $\mathrm{Fe}_{2} \mathrm{~N} @ \mathrm{OMC}-1, \mathrm{Fe}_{2} \mathrm{~N} @ \mathrm{OMC}-2$, and $\mathrm{Fe}_{2} \mathrm{~N} @ \mathrm{OMC}-3$, respectively. For further characterization of the porous structure of the prepared composites, the $\mathrm{N}_{2}$ adsorption-desorption isotherm (Fig. 4a) and pore size distribution curves (Fig. 4b) were obtained by nitrogen adsorption-desorption analysis. The samples $\mathrm{OMC}, \mathrm{Fe}_{2} \mathrm{~N} @ \mathrm{OMC}-1$, and $\mathrm{Fe}_{2} \mathrm{~N} @ \mathrm{OMC}-2$ exhibit type IV curves with an $\mathrm{H} 1$ hysteresis loop, which indicates the mesoporous nature of the synthesized composite materials due to the presence of OMC. In comparison, the $\mathrm{H} 1$ hysteresis loop cannot be observed in the $\mathrm{N}_{2}$ adsorption-desorption isotherm of $\mathrm{Fe}_{2} \mathrm{~N}$ and $\mathrm{Fe}_{2} \mathrm{~N} @ \mathrm{OMC}-3$ (Fig. 4a). The textural properties and parameters, such as the BET surface area $\left(S_{\mathrm{BET}}\right)$, the total pore volume $\left(V_{\mathrm{T}}\right)$, and the average pore diameter $\left(D_{\mathrm{BJH}}\right)$, are estimated, and the data value are summarized in Table 1 . The BET surface area, total pore volume, and average pore diameter of initial OMC are $1609 \mathrm{~m}^{2} \mathrm{~g}^{-1}, 2.13 \mathrm{~cm}^{3} \mathrm{~g}^{-1}$, and $5.29 \mathrm{~nm}$, respectively. The porosity development in the composite materials is gradually reduced with the increasing deposition of $\mathrm{Fe}_{2} \mathrm{~N}$ on the carbon surface. Particularly, when the content of $\mathrm{Fe}_{2} \mathrm{~N}$ increases to $57 \mathrm{wt} \%$ of $\mathrm{Fe}_{2} \mathrm{~N} @ \mathrm{OMC}-3$, the BET surface area significantly decreases from 1609 to $583 \mathrm{~m}^{2} \mathrm{~g}^{-1}$ from OMC to $\mathrm{Fe}_{2} \mathrm{~N} @ \mathrm{OMC}-3$ due to the blockage of the pore system by the big $\mathrm{Fe}_{2} \mathrm{~N}$ particles deposited on the external carbon surface, which can be detected in the TEM image in Fig. 3d. This finding is also supported by a significant decrease in the total pore volume from $2.13 \mathrm{~cm}^{3} \mathrm{~g}^{-1}$ for OMC to $0.44 \mathrm{~cm}^{3} \mathrm{~g}^{-1}$ for $\mathrm{Fe}_{2} \mathrm{~N} @ O M C-3$. For $\mathrm{Fe}_{2} \mathrm{~N} @ \mathrm{OMC}-1$, the porosity of $\mathrm{OMC}$ is preserved to a greater extent $\left(S_{\mathrm{BET}}: 1232 \mathrm{~m}^{2} \mathrm{~g}^{-1}, V_{\mathrm{T}}: 1.55 \mathrm{~cm}^{3} \mathrm{~g}^{-1}\right)$, but the content of $\mathrm{Fe}_{2} \mathrm{~N}$ is only $28 \mathrm{wt} \%$ of $\mathrm{Fe}_{2} \mathrm{~N} @ O M C-1$. The BET surface area of $\mathrm{Fe}_{2} \mathrm{~N} @ \mathrm{OMC}-2$ is much higher than that of $\mathrm{Fe}_{2} \mathrm{~N} @ O M C-3$ (919 vs. $583 \mathrm{~m}^{2} \mathrm{~g}^{-1}$ ). The total pore volume of $\mathrm{Fe}_{2} \mathrm{~N} @ O M C-2$ is $0.99 \mathrm{~cm}^{3} \mathrm{~g}^{-1}$, which is only two-fold lower than
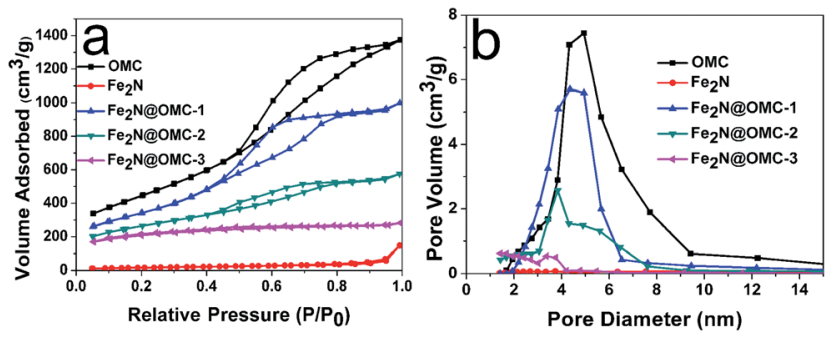

Fig. 4 The nitrogen adsorption-desorption isotherms (a) and pore diameter distribution (b) of $\mathrm{OMC}, \mathrm{Fe}_{2} \mathrm{~N}, \mathrm{Fe}_{2} \mathrm{NaOMC}-1, \mathrm{Fe}_{2} \mathrm{NaOMC}-2$, and $\mathrm{Fe}_{2} \mathrm{NaOMC}-3$.
Table 1 Porous property of composite materials identified by BET and $\mathrm{BJH}$

\begin{tabular}{lllc}
\hline Sample name & $S_{\mathrm{BET}}\left(\mathrm{m}^{2} \mathrm{~g}^{-1}\right)$ & $V_{\mathrm{T}}\left(\mathrm{cm}^{3} \mathrm{~g}^{-1}\right)$ & $D_{\mathrm{BJH}}(\mathrm{nm})$ \\
\hline OMC & 1609 & 2.13 & 5.29 \\
$\mathrm{Fe}_{2} \mathrm{~N}$ & 62 & 0.02 & 14.2 \\
$\mathrm{Fe}_{2} \mathrm{~N} @ O M C-1$ & 1232 & 1.55 & 5.03 \\
$\mathrm{Fe}_{2} \mathrm{~N} @ O M C-2$ & 919 & 0.99 & 4.88 \\
$\mathrm{Fe}_{2} \mathrm{~N} @ O M C-3$ & 583 & 0.44 & 2.62
\end{tabular}

that of OMC, $2.13 \mathrm{~cm}^{3} \mathrm{~g}^{-1}$. Moreover, the content of $\mathrm{Fe}_{2} \mathrm{~N}$ can reach $40.3 \mathrm{wt} \%$ of $\mathrm{Fe}_{2} \mathrm{~N} @ O M C-2$. The pore size distribution calculated from $D_{\mathrm{BJH}}$ reveals that the widths of pores are 5.29, $14.2,5.03,4.88$, and $2.62 \mathrm{~nm}$ in $\mathrm{OMC}, \mathrm{Fe}_{2} \mathrm{~N}, \mathrm{Fe}_{2} \mathrm{~N} @ \mathrm{OMC}-1$, $\mathrm{Fe}_{2} \mathrm{~N} @ \mathrm{OMC}-2$, and $\mathrm{Fe}_{2} \mathrm{~N} @ \mathrm{OMC}-3$, respectively.

$\mathrm{X}$-ray photoelectron spectroscopy (XPS) measurements were performed to analyze the surface information of the synthesized products. The surface iron concentration of $\mathrm{Fe}_{2} \mathrm{~N} @ \mathrm{OMC}-1$, $\mathrm{Fe}_{2} \mathrm{~N} @ \mathrm{OMC}-2$, and $\mathrm{Fe}_{2} \mathrm{~N} @ \mathrm{OMC}-3$ is $1.7,6.2$, and 14.6 at $\%$, respectively (Table $\mathrm{S} 1$, ESI $\dagger$ ). The $\mathrm{N}$ 1s XPS spectra of $\mathrm{Fe}_{2}$ N@OMC-2 (Fig. 5c) and $\mathrm{Fe}_{2} \mathrm{~N} @ O M C-3$ (Fig. 5e) were divided into five component peaks, which corresponded to nitrogen bonded with metal nitride $(\sim 397.6 \mathrm{eV})$, pyridinic- $\mathrm{N}(\sim 398.4 \mathrm{eV})$, pyrrolic-N $(\sim 399.8 \mathrm{eV})$, graphitic-N $(\sim 400.8 \mathrm{eV})$, and nitrogen oxide ( $\sim 401.9 \mathrm{eV})$ functionalities. ${ }^{29,38}$ The $\mathrm{N} 1 \mathrm{~s}$ XPS spectrum of
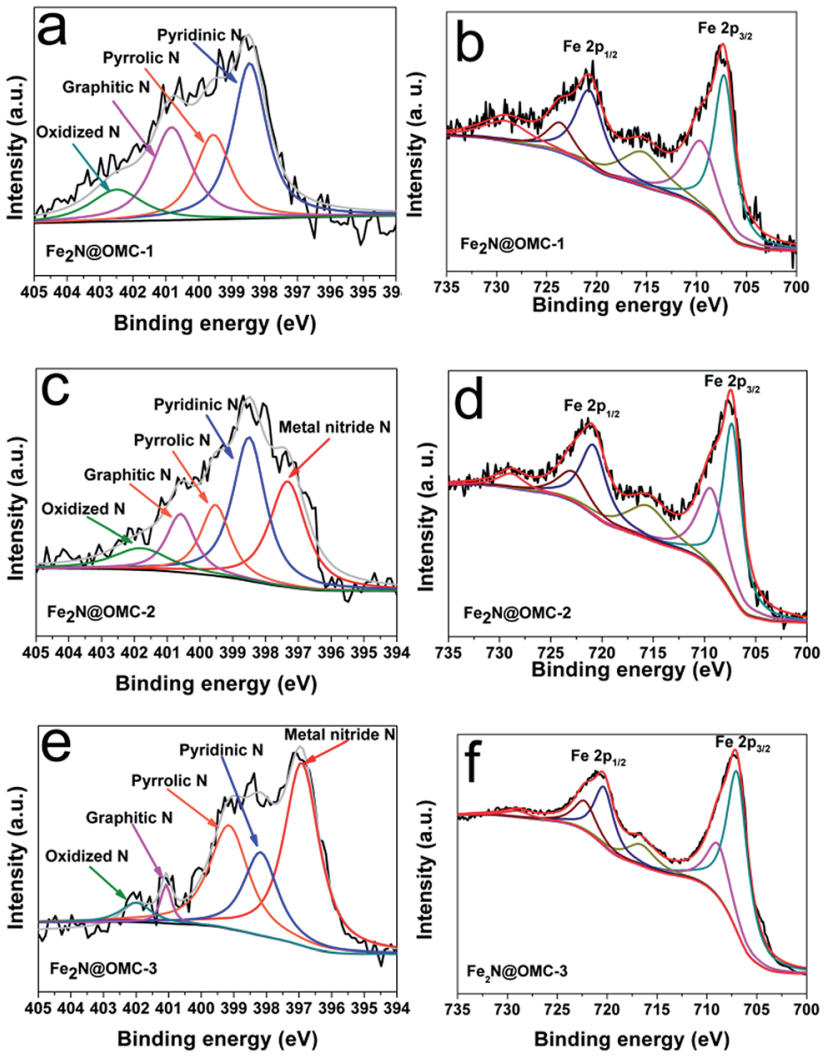

Fig. 5 High-resolution XPS spectra of $\mathrm{N}$ 1s of $\mathrm{Fe}_{2} \mathrm{NaOMC}-1$ (a), $\mathrm{Fe}_{2}-$ $\mathrm{NaOMC}-2$ (c), and $\mathrm{Fe}_{2} \mathrm{NaOMC}-3$ (e). Fe $2 \mathrm{p}$ spectra of $\mathrm{Fe}_{2} \mathrm{NaOMC}-1$ (b), $\mathrm{Fe}_{2} \mathrm{NaOMC}-2$ (d), and $\mathrm{Fe}_{2} \mathrm{NaOMC}-3$ (f). 
$\mathrm{Fe}_{2} \mathrm{~N} @ \mathrm{OMC}-1$ indicates no metal nitride functionality (Fig. 5a) as compared to that of $\mathrm{Fe}_{2} \mathrm{~N} @ \mathrm{OMC}-2$ and $\mathrm{Fe}_{2} \mathrm{~N} @ \mathrm{OMC}-3$, whereas $\mathrm{Fe}_{2} \mathrm{~N}$ really exists in the $\mathrm{Fe}_{2} \mathrm{~N} @ \mathrm{OMC}-1$, as demonstrated by XRD analysis. This finding indicated that iron nitride also exists in the pores of OMC and this part of iron nitride cannot be detected via XPS, which also applies to $\mathrm{Fe}_{2} \mathrm{~N} @ \mathrm{OMC}-2$ and $\mathrm{Fe}_{2} \mathrm{~N} @ \mathrm{OMC}-3$. The high-resolution XPS spectrum of the asmade samples for the Fe $2 \mathrm{p}$ level exhibits main peaks at around 707.5 and $721.4 \mathrm{eV}$ that correspond to the $\mathrm{Fe} 2 \mathrm{p}_{3 / 2}$ and $\mathrm{Fe} 2 \mathrm{p}_{1 / 2}$ levels, respectively. They are assigned to $\mathrm{Fe}(\mathrm{II})$ in iron nitride. Moreover, the peaks appear at 710.0, 715.6, 723.8, and $729.1 \mathrm{eV}$, which are attributed to the presence of Fe-O bonds. ${ }^{\mathbf{4 1 , 4 2}}$ The electrochemical performance of the obtained samples was analyzed in a standard three electrode system. The cyclic voltammogram of OMC shows a rectangular and symmetric shape, indicating a typical electric double-layer (EDL) behaviour, and all cyclic voltammograms of $\mathrm{Fe}_{2} \mathrm{~N}$-containing samples exhibit undoubtedly the reversible faradaic redox reactions attributing to $\mathrm{Fe}_{2} \mathrm{~N}$, as shown in Fig. 6a. All the composites of $\mathrm{Fe}_{2} \mathrm{~N} @ O M C-1$, $\mathrm{Fe}_{2} \mathrm{~N} @ O M C-2$, and $\mathrm{Fe}_{2} \mathrm{~N} @ O M C-3$ have sharper and higher redox peaks as compared to bare $\mathrm{Fe}_{2} \mathrm{~N}$; this indicates that the presence of OMC can effectively enhance the electrochemical performance of these composites due to better utilization of $\mathrm{Fe}_{2} \mathrm{~N}$ during charging and discharging when $\mathrm{Fe}_{2} \mathrm{~N}$ is evenly
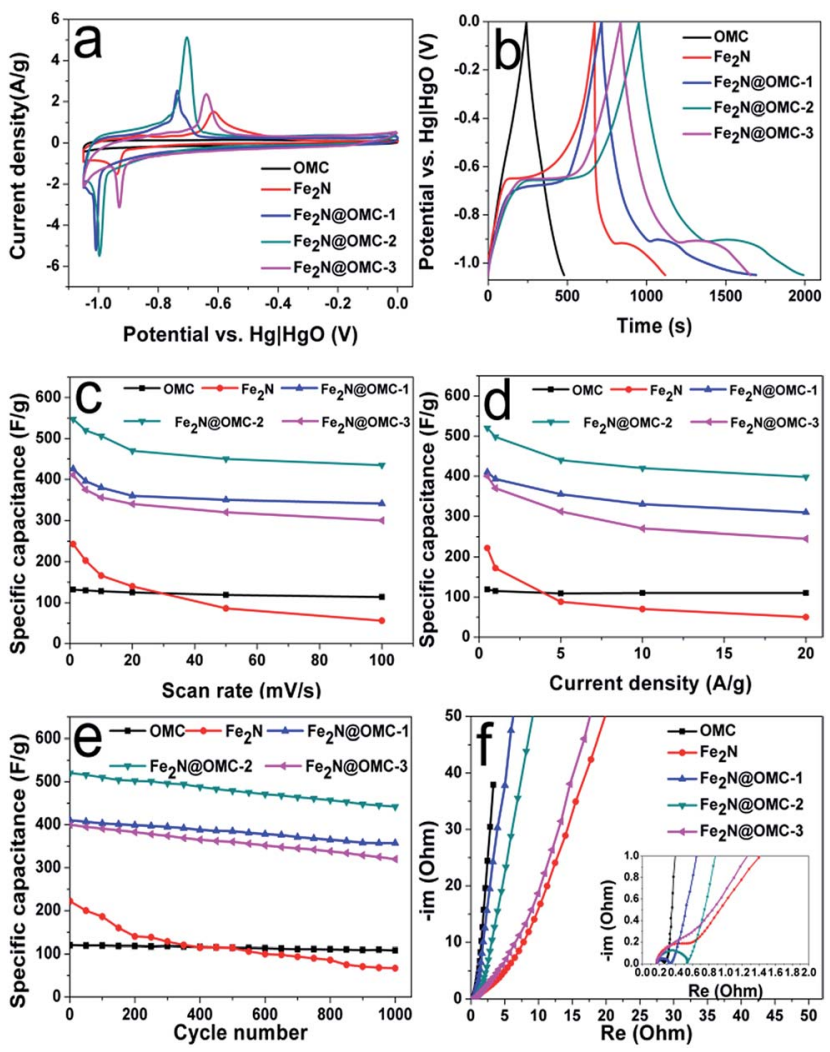

Fig. 6 Cyclic voltammograms of the synthetic products at $1 \mathrm{mV} \mathrm{s}^{-1}($ a), galvanostatic charge/discharge curves performed at $0.5 \mathrm{~A} \mathrm{~g}^{-1}$ (b), specific capacitance as a function of the scan rate (c) and current density (d), cycle stability at a current density of $1 \mathrm{~A} \mathrm{~g}^{-1}(e)$, and Nyquist plots with an inset representing the high-frequency region (f). distributed on the surface of OMC. The higher specific surface area of $\mathrm{Fe}_{2} \mathrm{~N} @ \mathrm{OMC}-2$, which implies a better distribution of $\mathrm{Fe}_{2} \mathrm{~N}$ particles on the surface of OMC as compared to that of $\mathrm{Fe}_{2} \mathrm{~N} @ \mathrm{OMC}-3$, is a reason for the stronger pseudocapacitive behavior reflected by the voltammetry curve. However, excessive specific surface area of $\mathrm{Fe}_{2} \mathrm{~N} @ \mathrm{OMC}-1$ will sacrifice the content of $\mathrm{Fe}_{2} \mathrm{~N}$, thereby decreasing the electrochemical pseudocapacity, which is not expected. For $\mathrm{Fe}_{2} \mathrm{~N} @ \mathrm{OMC}-1, \mathrm{Fe}_{2} \mathrm{~N} @ \mathrm{OMC}-2$, and $\mathrm{Fe}_{2} \mathrm{~N} @ \mathrm{OMC}-3$ composites, both the charge storage mechanism of the electric double-layer behavior and faradaic redox reactions derived from $\mathrm{OMC}$ and $\mathrm{Fe}_{2} \mathrm{~N}$, respectively, must be investigated and studied. In Fig. 6b, a symmetrical triangular can be observed remarkably in the galvanostatic chargedischarge curves of OMC, which demonstrates that OMC has an outstanding double-layer capacitance and the platforms of the triangular shape shown by the galvanostatic charge-discharge curves of $\mathrm{Fe}_{2} \mathrm{~N}, \mathrm{Fe}_{2} \mathrm{~N} @ \mathrm{OMC}-1, \mathrm{Fe}_{2} \mathrm{~N} @ \mathrm{OMC}-2$, and $\mathrm{Fe}_{2} \mathrm{~N} @ \mathrm{OMC}-3$ correspond to the redox peaks of cyclic voltammogram at $-0.75 \div-0.62 \mathrm{~V}$ and $-1.05 \div-0.94 \mathrm{~V}$. Moreover, it was obvious that the discharge time curves (Fig. S3 ESI $\dagger$ ) of synthetic products were in the order of OMC $<\mathrm{Fe}_{2} \mathrm{~N}<\mathrm{Fe}_{2} \mathrm{~N} @ O M C-3<$ $\mathrm{Fe}_{2} \mathrm{~N} @ O M C-1<\mathrm{Fe}_{2} \mathrm{~N} @ O M C-2$. For $\mathrm{Fe}_{2} \mathrm{~N} @ O M C-2$, excellent capacitance values of $547 \mathrm{~F} \mathrm{~g}^{-1}$ at $1 \mathrm{mV} \mathrm{s}^{-1}$ and $520 \mathrm{~F} \mathrm{~g}^{-1}$ at $0.5 \mathrm{~A} \mathrm{~g}^{-1}$ can be calculated by voltammetry and galvanostatic charge-discharge. $\mathrm{Fe}_{2} \mathrm{~N} @ \mathrm{OMC}-2$ has better specific capacitance as compared to those reported in other studies, ${ }^{37,38}$ as shown in Table S2. $\dagger$ In the application of supercapacitors, the material of the OMC-based $\mathrm{Fe}_{2} \mathrm{~N}$ composite with very high specific capacitance has never been synthesized before. The capacitance of $\mathrm{Fe}_{2} \mathrm{~N} @ \mathrm{OMC}-2$ is more than two times that of bare $\mathrm{Fe}_{2} \mathrm{~N}$ at $1 \mathrm{mV} \mathrm{s}^{-1}$ and $0.5 \mathrm{~A} \mathrm{~g}^{-1}$ and dramatically decreases in the strong current and high scan rate regions (Fig. 6c and d). The specific capacitances of $\mathrm{Fe}_{2} \mathrm{~N} @ \mathrm{OMC}-1, \mathrm{Fe}_{2} \mathrm{~N} @ \mathrm{OMC}-2$, and $\mathrm{Fe}_{2} \mathrm{~N} @ \mathrm{OMC}-3$ were 310,398 , and $245 \mathrm{~F} \mathrm{~g}^{-1}$ at a high current density of $20 \mathrm{~A} \mathrm{~g}^{-1}$, maintaining 75, 76, and $61 \%$ of the initial capacitance at $0.5 \mathrm{~A} \mathrm{~g}^{-1}$. For comparison, bare $\mathrm{Fe}_{2} \mathrm{~N}$ exhibits a specific capacitance of only $50 \mathrm{~F} \mathrm{~g}^{-1}$ at a current density of $20 \mathrm{~A} \mathrm{~g}^{-1}$; this fully illustrates the significance of OMC of carbon-based $\mathrm{Fe}_{2} \mathrm{~N}$ composite in improving the energy density. In addition, for supercapacitors, the cyclic stability is another indispensable performance indicator. All the prepared products were run for 1000 charge-discharge cycles at a current density of $1 \mathrm{~A} \mathrm{~g}^{-1}$, as shown in Fig. 6e. It can be seen that all carbon-based $\mathrm{Fe}_{2} \mathrm{~N}$ composites show excellent cyclic stability after 1000 cycles due to a high specific surface area and the appropriate porous size. Particularly, $\mathrm{Fe}_{2} \mathrm{~N} @ \mathrm{OMC}-2$ shows a much higher retention of $85 \%$ of the initial capacitance as compared to bare $\mathrm{Fe}_{2} \mathrm{~N}$, which exhibits only $28 \%$ retention. Moreover, it was clearly observed that only a very small amount of $\mathrm{Fe}_{2} \mathrm{~N}$ nanoparticles of $\mathrm{Fe}_{2} \mathrm{~N} @ O M C-2$ accumulated after 1000 cycles (Fig. S4b ESI $\dagger$ ) compared to those before 1000 cycles (Fig. S4a ESI $\dagger$ ). The stable nanostructure made the $\mathrm{Fe}_{2} \mathrm{~N} @ O M C-2$ electrode have an outstanding cyclic stability. The nanocasting route can achieve a homogeneous dispersion of small non-aggregated $\mathrm{Fe}_{2} \mathrm{~N}$ nanoparticles on the external surface and in the pores of OMC; this has been demonstrated by nitrogen sorption analysis, SEM, TEM, HRTEM, and XPS results. This feature can improve the 
transport of ions from the bulk electrolyte to the composite material. The collective effect of the two factors, OMC providing more active sites due to the high specific surface area and the high pseudocapacitance of $\mathrm{Fe}_{2} \mathrm{~N}$, accounts for the outstanding electrochemical performance of the $\mathrm{Fe}_{2} \mathrm{~N} @ \mathrm{OMC}-2$ composite as an electrode material for supercapacitors. ${ }^{38}$

The resistive characteristics of electrode materials were analyzed by EIS (Fig. 6f). In the Nyquist plots of $\mathrm{OMC}, \mathrm{Fe}_{2}$ $\mathrm{N} @ \mathrm{OMC}-1$, and $\mathrm{Fe}_{2} \mathrm{~N} @ \mathrm{OMC}-2$, a small semicircular line corresponding to the interfacial charge-transfer resistance is noticed in the high-frequency region, which indicates that all the samples OMC, $\mathrm{Fe}_{2} \mathrm{~N} @ \mathrm{OMC}-1$, and $\mathrm{Fe}_{2} \mathrm{~N} @ \mathrm{OMC}-2$ have a small charge-transfer resistance. The slope lines at an angle of $80-90^{\circ}$ are observed markedly in the lower frequency region of $\mathrm{OMC}$, $\mathrm{Fe}_{2} \mathrm{~N} @ O M C-1$, and $\mathrm{Fe}_{2} \mathrm{~N} @ O M C-2$, which show an excellent charge-discharge capacitive behavior because of the fast charge-transfer rate from the active electrode material to the current collector. ${ }^{\mathbf{4 0 4 3}}$ By contrast, no obvious semicircle is detected for bare $\mathrm{Fe}_{2} \mathrm{~N}$ and $\mathrm{Fe}_{2} \mathrm{~N} @ \mathrm{OMC}-3$; this demonstrates the presence of charge-transfer resistance, resulting in a poor rate capability. ${ }^{44}$ In addition, the slope lines at an angle near $45^{\circ}$ for $\mathrm{Fe}_{2} \mathrm{~N}$ and $\mathrm{Fe}_{2} \mathrm{~N} @ O M C-3$ reveal the occurrence of the Warburg impedance, standing for ion-diffusion resistance. ${ }^{\mathbf{4 0 4 5}}$ The ion-diffusion resistance of $\mathrm{Fe}_{2} \mathrm{~N}$ and $\mathrm{Fe}_{2} \mathrm{~N} @ O M C-3$ is higher than that of $\mathrm{OMC}, \mathrm{Fe}_{2} \mathrm{~N} @ \mathrm{OMC}-1$, and $\mathrm{Fe}_{2} \mathrm{~N} @ \mathrm{OMC}-2$; this may be caused by the aggregated and bulky particles of $\mathrm{Fe}_{2} \mathrm{~N}$, making ion diffusion in the electrolyte become more difficult. ${ }^{46}$ The EIS measurements can further prove that the composite of $\mathrm{OMC}$ and small non-aggregated $\mathrm{Fe}_{2} \mathrm{~N}$ particles is advantageous in ion-transport, which plays a significant role in rate performance and specific capacitance.

Different electrolytes can better test the performance of the electrodes. ${ }^{47}$ The $\mathrm{Fe}_{2} \mathrm{~N} @ O M C-2$ electrode was tested in $1 \mathrm{M}$ $\mathrm{LiOH}, \mathrm{NaOH}$, and $\mathrm{KOH}$ electrolytes, as shown in Fig. S5 ESI. $\dagger$ It is clear that the redox peaks of CV curves increase in turn as the size of the cations in the electrolytes decreases $\left(\mathrm{K}^{+}>\mathrm{Na}^{+}>\mathrm{Li}^{+}\right)$. This observation indicates enhanced pseudocapacitive reactions with smaller cations as they are easier to get intercalated into the pores of $\mathrm{Fe}_{2} \mathrm{~N} @ \mathrm{OMC}-2$. Moreover, we tested the cyclic stability in different electrolytes ( $\mathrm{LiOH}, \mathrm{NaOH}$, and $\mathrm{KOH})$. After 1000 cycles, the specific capacitance retention of $\mathrm{Fe}_{2} \mathrm{~N} @ \mathrm{OMC}-2$ remained to be $87 \%$ in $\mathrm{KOH}$, which was much higher than that in $\mathrm{LiOH}(67 \%)$ and $\mathrm{NaOH}(72 \%)$. This is mainly because the smaller cation is difficult to desorb from the pore of the as-made electrode materials.

\section{Conclusions}

A novel $\mathrm{Fe}_{2} \mathrm{~N} @ \mathrm{OMC}-2$ composite was successfully synthesized via a nanocasting route and $\mathrm{NH}_{3}$ annealing. The vacuum impregnation of OMC with iron chloride resulted in the deposition of small and non-aggregated $\mathrm{Fe}_{2} \mathrm{~N}$ nanoparticles both on the external surface and in the pores of OMC. Owing to the synergistic effect between the mesoporous property of OMC and an excellent pseudocapacitance of $\mathrm{Fe}_{2} \mathrm{~N}, \mathrm{Fe}_{2} \mathrm{~N} @ \mathrm{OMC}-2$ exhibits an eye-catching high capacitance of $547 \mathrm{~F} \mathrm{~g}^{-1}$ at $1 \mathrm{mV} \mathrm{s}^{-1}$. A great rate capability of $76 \%$ was retained when the current densities increased from 0.5 to $20 \mathrm{~A} \mathrm{~g}^{-1}$, and a superior cyclic stability of $85 \%$ was retained after 1000 cycles. This study constitutes the first demonstration of employing the composite of $\mathrm{Fe}_{2} \mathrm{~N}$ and $\mathrm{OMC}$ as an electrode material for supercapacitors, which can effectively enhance the performance of energy storage devices.

\section{Conflicts of interest}

There are no conflicts to declare.

\section{Acknowledgements}

We gratefully acknowledge the support for this study provided by the National Natural Science Foundation of China (No. 21501104), the Natural Science Foundation of Heilongjiang Province (B2015014), and the University Nursing Program for Young Scholars with Creative Talents in Heilongjiang Province (UNPYSCT-2016088).

\section{Notes and references}

1 S. L. Chiam, H. N. Lim, C. Y. Foo, A. Pandikumar and N. M. Huang, Electrochim. Acta, 2017, 246, 1141-1146.

2 Y. Liu and X. Peng, Applied Materials Today, 2017, 8, 104-115.

3 H. Yang and Y. Zhang, J. Power Sources, 2016, 312, 165-171.

4 K.-T. Lee, C.-B. Tsai, W.-H. Ho and N.-L. Wu, Electrochem. Commun., 2010, 12, 886-889.

5 X. Meng and R. Wang, Energy Procedia, 2012, 17, 1585-1590.

6 J. Lv, Z. Wang, T. Liang, Y. Meng, K. Suzuki and H. Miura, J. Electroanal. Chem., 2017, 799, 595-601.

7 L. Liu, H. Zhang, L. Fang, Y. Mu and Y. Wang, J. Power Sources, 2016, 327, 135-144.

8 X. Liu, A. Zhou, T. Pan, Y. Dou, M. Shao, J. Han and M. Wei, J. Mater. Chem. A, 2016, 4, 8421-8427.

9 Z. Yu, C. Li, D. Abbitt and J. Thomas, J. Mater. Chem. A, 2014, 2, 10923-10929.

10 C. Li, M. M. Islam, J. Moore, J. Sleppy, C. Morrison, K. Konstantinov, S. X. Dou, C. Renduchintala and J. Thomas, Nat. Commun., 2016, 7, 13319.

11 D. Yang, J. Power Sources, 2011, 196, 8843-8849.

12 H. Chang and H. Wu, Energy Environ. Sci., 2013, 6, 34833507.

13 M. S. Javed, C. Zhang, L. Chen, Y. Xi and C. Hu, J. Mater. Chem. A, 2016, 4, 8851-8859.

14 L. Ma, L. Su, J. Zhang, D. Zhao, C. Qin, Z. Jin and K. Zhao, J. Electroanal. Chem., 2016, 777, 75-84.

15 M. Idrees, S. M. Abbas, R. Ata Ur, N. Ahmad, M. W. Mushtaq, R. A. Naqvi, K.-W. Nam, B. Muhammad and Z. Iqbal, J. Chem. Eng., 2017, 327, 361-370.

16 B. Das, M. V. Reddy and B. V. Chowdari, Nanoscale, 2013, 5, 1961-1966.

17 P. J. Hanumantha, M. K. Datta, K. Kadakia, C. Okoli, P. Patel and P. N. Kumta, Electrochim. Acta, 2016, 207, 37-47.

18 N. Choudhary, C. Li, J. Moore, N. Nagaiah, L. Zhai, Y. Jung and J. Thomas, Adv. Mater., 2017, 29, 1605336. 
19 X. Lu, G. Wang, T. Zhai, M. Yu, S. Xie, Y. Ling, C. Liang, Y. Tong and Y. Li, Nano Lett., 2012, 12, 5376-5381.

20 M. Yu, Y. Han, X. Cheng, L. Hu, Y. Zeng, M. Chen, F. Cheng, X. Lu and Y. Tong, Adv. Mater., 2015, 27, 3085-3091.

21 N. Mosavati, S. O. Salley and K. Y. S. Ng, J. Power Sources, 2017, 340, 210-216.

22 S. Dong, X. Chen, X. Zhang and G. Cui, Coord. Chem. Rev., 2013, 257, 1946-1956.

23 S. Liu, J. Liu, W. Wang, L. Yang, K. Zhu and H. Wang, RSC Adv., 2016, 6, 86131-86136.

24 Y. Yu, W. Gao, Z. Shen, Q. Zheng, H. Wu, X. Wang, W. Song and K. Ding, J. Mater. Chem. A, 2015, 3, 16633-16641.

25 L. Jiang, L. Lin, F. Yan, B. Fan, Y. Chen and Y. Qiu, Ceram. Int., 2017, 43, 9226-9234.

26 G. R. Li, J. Song, G. L. Pan and X. P. Gao, Energy Environ. Sci., 2011, 4, 1680.

27 H. Huang, S. Gao, A.-M. Wu, K. Cheng, X.-N. Li, X.-X. Gao, J.-J. Zhao, X.-L. Dong and G.-Z. Cao, Nano Energy, 2017, 31, 74-83.

28 D. Di Lecce, R. Verrelli and J. Hassoun, Green Chem., 2017, 19, 3442-3467.

29 T. Panja, D. Bhattacharjya and J.-S. Yu, J. Mater. Chem. A, 2015, 3, 18001-18009.

30 Y. Teng, E. Liu, R. Ding, K. Liu, R. Liu, L. Wang, Z. Yang and H. Jiang, Electrochim. Acta, 2016, 194, 394-404.

31 J.-G. Wang, Y. Yang, Z.-H. Huang and F. Kang, Carbon, 2013, 61, 190-199.

32 Y. Xie, L. Lu, Y. Tang, F. Zhang, C. Shen, X. Zang, X. Ding, W. Cai and L. Lin, Mater. Lett., 2017, 186, 70-73.

33 L. Feng, G. Li, S. Zhang and Y. X. Zhang, Ceram. Int., 2017, 43, 8321-8328.
34 X. Zhang, J. Luo, P. Tang, X. Ye, X. Peng, H. Tang, S.-G. Sun and J. Fransaer, Nano Energy, 2017, 31, 311-321.

35 V. C. Lokhande, A. C. Lokhande, C. D. Lokhande, J. H. Kim and T. Ji, J. Alloys Compd., 2016, 682, 381-403.

36 L.-Q. Fan, G.-J. Liu, J.-H. Wu, L. Liu, J.-M. Lin and Y.-L. Wei, Electrochim. Acta, 2014, 137, 26-33.

37 C. Zhu, P. Yang, D. Chao, X. Wang, X. Zhang, S. Chen, B. K. Tay, H. Huang, H. Zhang, W. Mai and H. J. Fan, Adv. Mater., 2015, 27, 4566-4571.

38 A. Sliwak, A. Moyseowicz and G. Gryglewicza, J. Mater. Chem. $A, 2017,5,5680-5684$.

39 J. Feng, W. Song, L. Sun and L. Xu, RSC Adv., 2016, 6, 110337110343.

40 M.-S. Balogun, M. Yu, Y. Huang, C. Li, P. Fang, Y. Liu, X. Lu and Y. Tong, Nano Energy, 2015, 11, 348-355.

41 P. Yu, L. Wang, F. Sun, D. Zhao, C. Tian, L. Zhao, X. Liu, J. Wang and H. Fu, Chem.-Eur. J., 2015, 21, 3249-3256.

42 B. P. Vinayan, T. Diemant, R. J. Behm and S. Ramaprabhu, RSC Adv., 2015, 5, 66494-66501.

43 L. Ren, G. Zhang, Z. Yan, L. Kang, H. Xu, F. Shi, Z. Lei and Z. H. Liu, ACS Appl. Mater. Interfaces, 2015, 7, 28294-28302.

44 F. Miao, C. Shao, X. Li, K. Wang and Y. Liu, J. Mater. Chem. A, 2016, 4, 4180-4187.

45 J. Huang, S. Yang, Y. Xu, X. Zhou, X. Jiang, N. Shi, D. Cao, J. Yin and G. Wang, J. Electroanal. Chem., 2014, 713, 98-102.

46 B. Liang, Z. Qin, T. Li, Z. Dou, F. Zeng, Y. Cai, M. Zhu and Z. Zhou, Electrochim. Acta, 2015, 177, 335-342.

47 N. Choudhary, C. Li, H. S. Chung, J. Moore, J. Thomas and Y. Jung, ACS Nano, 2016, 10, 10726-10735. 